\title{
Male broiler performance and nocturnal feeding under constant 8-h or 16-h photoperiods, and various increasing lighting regimens
}

\author{
P.D. Lewis ${ }^{\#}$, R. Danisman and R.M. Gous \\ Animal and Poultry Science, School of Agricultural Sciences and Agribusiness, University of KwaZulu-Natal, \\ Scottsville 3209, South Africa
}

\begin{abstract}
This paper describes the responses of two genotypes of male broilers to constant 8- and 16-h photoperiods, and to an abrupt transfer from 8 to $16 \mathrm{~h}$ at 10,15 or $20 \mathrm{~d}$. Body weight, feed intake, and feed conversion efficiency were not significantly different at any stage during the $35 \mathrm{~d}$ study. Mortality and the incidence of Sudden Death Syndrome were similar for all lighting groups at $35 \mathrm{~d}$. When these data were pooled with previously reported data for female broilers, growth and feed conversion efficiency post $21 \mathrm{~d}$ and through to depletion for constant 8-h and birds transferred from 8 to $16 \mathrm{~h}$ at $20 \mathrm{~d}$ were significantly superior to constant 16-h birds. Constant 8 -h birds ate about half their feed during the dark period, whilst 16-h birds consumed no more than 10\%. Birds which had been started on $8 \mathrm{~h}$ and transferred to $16 \mathrm{~h}$ at 10 , 15 or $20 \mathrm{~d}$ reduced their rate of nocturnal feeding when changed to the longer photoperiod, however, they still consumed more feed in the 8-h dark period than birds that had always been given $16 \mathrm{~h}$ illumination. Cobb and Ross genotypes responded similarly to all lighting treatments.
\end{abstract}

Keywords: Photoperiod, broiler growth, nocturnal feeding

\# Corresponding author. E-mail: pdlewis@dsl.pipex.com

\section{Introduction}

Photoperiodic responses and the influence of increasing lighting regimens were reviewed in an earlier paper that reported the responses of female broilers to a constant 8- or 16-h photoperiod or to an increase from 8 to $16 \mathrm{~h}$ at $21 \mathrm{~d}$ of age (Lewis \& Gous, 2007). Increasing lighting programmes were developed to improve liveability in broiler flocks, in particular, through a reduction in the incidences of Sudden Death Syndrome and leg abnormalities (e.g., Classen \& Riddell, 1989). In the original experiments, broilers were started on 6-h photoperiods and transferred to $23 \mathrm{~h}$ at $21 \mathrm{~d}$, however, such lighting regimens do not comply with current animal welfare codes in many countries because the initial photoperiod is shorter than $8 \mathrm{~h}$. It is likely that welfare codes for broiler production will be made even more stringent in the future, especially in Europe, with the stipulation of a minimum period of darkness. Codes for growing turkeys already require at least $4 \mathrm{~h}$, but ideally $8 \mathrm{~h}$, of uninterrupted darkness. It was considered prudent therefore to study responses to an increasing lighting schedule that would comply with current and future welfare codes. The present study with males, and an earlier one with females (Lewis \& Gous, 2007), compared the performance of two genotypes of broiler maintained on 8- or 16-h photoperiods with that of birds started on $8 \mathrm{~h}$ and transferred to $16 \mathrm{~h}$ at about three weeks. Growth in modern genotypes of broiler is faster than that of the genotypes used in the original trials (approximately $600 \mathrm{~g}$ at $21 \mathrm{~d}$ reported by Classen \& Riddell (1989) but $800 \mathrm{~g}$ in the current trials), and so this study included transfers from 8 to $16 \mathrm{~h}$ at 10, 15, and $20 \mathrm{~d}$. Lewis \& Morris (2006) concluded that whilst body weight gain increased with photoperiod during the initial $21 \mathrm{~d}$, but decreased beyond $21 \mathrm{~d}$ for photoperiods longer than $12 \mathrm{~h}$, birds maintained on $8 \mathrm{~h}$ consistently had inferior growth and lower feed intakes at all ages. However, in the earlier study with females, body weight at $42 \mathrm{~d}$ was significantly higher and feed intake numerically greater for 8-h birds than for those held on $16 \mathrm{~h}$, and it was suggested that the increased appetite of the modern broiler had resulted in it learning to eat more feed in the dark period than its ancestors.

The objective of this trial was to study the response of broiler males to constant 8- or 16-h photoperiods, or to a transfer from 8 to $16 \mathrm{~h}$ photoperiods at 10,15 or $21 \mathrm{~d}$, and to assess the influence of the lighting regimens and age on the amount of nocturnal feeding performed. 


\section{Materials \& Methods}

Cobb 500 and Ross 308 male broilers were vent sexed for maximum accuracy and placed at $1 \mathrm{~d}$ of age on the litter floor in each of 10 lightproof rooms. Each room was subdivided into two pens by a wire mesh fence, and 200 Cobb or 200 Ross birds placed in each pen at a stocking density of $8.4 / \mathrm{m}^{2}$ (at $35 \mathrm{~d} \approx 19 \mathrm{~kg} / \mathrm{m}^{2}$ at depletion). All birds were given constant illumination for the first day and transferred to one of the following lighting regimens on day 2 (two rooms per treatment): constant $8 \mathrm{~h}$, constant $16 \mathrm{~h}$, an initial $8 \mathrm{~h}$ followed by a transfer to $16 \mathrm{~h}$ at $10 \mathrm{~d}$ (INC10), $15 \mathrm{~d}$ (INC15) or $20 \mathrm{~d}$ (INC20); 5 lighting treatments $\mathrm{x}$ 2 rooms $\times 2$ genotypes $\times 200$ birds $=4000$ birds. In each pen, illumination was provided by two $11 \mathrm{~W}$ compact warm-white fluorescent lamps located $1.8 \mathrm{~m}$ above the floor, giving a mean illuminance of $29 \pm 2.3$ lux at a height of $20 \mathrm{~cm}$. During the initial 7-d brooding period, illuminance within the brooder surround varied between 0.02 and 0.07 lux during the scotoperiod, thereafter it was completely dark All groups received the same feeding regimen: $1 \mathrm{~kg} / \mathrm{bird}$ of a proprietary broiler starter crumb $(12.8 \mathrm{MJ} \mathrm{ME} / \mathrm{kg}, 200$ $\mathrm{g} / \mathrm{kg}$ of crude protein) - consumed in approximately $21 \mathrm{~d}$ - followed by a broiler grower pellet (12.8 MJ $\mathrm{ME} / \mathrm{kg} \mathrm{ME}, 160 \mathrm{~g} / \mathrm{kg}$ of crude protein) until depletion at $35 \mathrm{~d}$. Initially the feed was provided on feeder bases, but it was delivered from manually filled hanging tube feeders after $7 \mathrm{~d}$.

A sample of 60 birds from each pen was bulk-weighed at 7-d intervals between 7 and $28 \mathrm{~d}$, and all birds were bulk-weighed at $35 \mathrm{~d}$. Feed was weighed back weekly. Mortality was recorded daily, and any ailing birds examined for signs of leg disorder and, if necessary, culled on welfare grounds. All carcasses were examined for signs of leg disorder or Sudden Death Syndrome (SDS: large birds that had died on their backs).

Feed weigh-backs were performed weekly from $5 \mathrm{~d}$ of age in one room from each of the five lighting treatments at the beginning of the photoperiod, $10 \mathrm{~min}$ before lights-out, and at the beginning of the next photoperiod to determine diurnal and nocturnal feed intakes.

All performance data were subjected to a split-plot ANOVA with light as the main-plot and genotype as the subplot (Analytical Software, 2003). Mortality and SDS data were given an arcsine transformation prior to analysis. Significant differences between treatments were identified using a Students $t$-test. Nocturnal and diurnal feed intakes were only recorded in one of two rooms for each lighting treatments, so these data are only presented graphically. Differences between genotypes for feeding behaviour were assessed using a repeated measures ANOVA.

Data for constant 8 or $16 \mathrm{~h}$ and transfers from 8 to $16 \mathrm{~h}$ at $20 \mathrm{~d}$ in this study were combined with equivalent data for females from the earlier trial (Lewis \& Gous, 2007) and subjected to a split-plot ANOVA with light as the main-plot and genotype as the subplot to assess the general response to these lighting regimens.

\section{Results}

At no stage were there significant differences between lighting treatments for mean body weight, feed intake, or feed conversion efficiency (Table 1). Whilst total mortality between 22 and $35 \mathrm{~d}$ for birds maintained on 8 -h photoperiods was significantly higher than for constant 16 -h birds, with the three INC groups intermediate, total mortality to $21 \mathrm{~d}$ and throughout the $35 \mathrm{~d}$ were not significantly different for any of the lighting treatments. The incidence of SDS was generally low throughout the trial, but birds held on 8-h photoperiods had a significantly higher incidence in the 22 to $35-\mathrm{d}$ period than birds transferred from 8 to $16 \mathrm{~h}$ at $15 \mathrm{~d}$; other groups were intermediate (Table 1). The number of leg disorders was minimal throughout the trial for all groups, and so these data are not reported.

Cobb birds were significantly heavier than Ross birds at $21 \mathrm{~d}$, but not significantly different at $35 \mathrm{~d}$ (Table 1). Feed intakes, feed conversion efficiencies, and total mortality were not significantly different at any stage. Although Cobb had a significantly higher incidence of SDS than Ross birds between 21 and $35 \mathrm{~d}$, the differences during the first $21 \mathrm{~d}$ and through the trial as a whole were not significantly different.

Irrespective of genotype and at all ages, birds maintained on 8-h photoperiods ate about half their daily feed intake during the 16-h dark period (Figure 1). In contrast, constant 16-h birds consumed only 5 to 10 percent of their feed during their 'night'. Nocturnal feeding by the INC birds decreased after they were transferred to 16-h photoperiods, although they continued to consume more feed in the 8-h night than constant long-day birds. At no age was Cobb feeding behaviour significantly different from Ross. 
The analysis of pooled data for males from this study and females from Lewis \& Gous (2007) showed that mean body weight and feed conversion efficiencies during the initial $21 \mathrm{~d}$ for constant 8 -h birds was not significantly different from that of birds held on $16 \mathrm{~h}$, despite the latter birds consuming significantly more feed (Table 2). After $21 \mathrm{~d}$, birds maintained on $8 \mathrm{~h}$ consumed significantly more feed, converted feed more efficiently, and had a significantly greater body weight gain than constant-16-h birds. Subsequent to being transferred from 8 to $16 \mathrm{~h}$ and cumulatively to depletion, all INC groups had significantly greater body-

Table 1 Body weight at, and feed intake, feed conversion efficiency (FCE), total mortality, and incidence of Sudden Death Syndrome to, $21 \mathrm{~d}$, between 22 to $35 \mathrm{~d}$, and at $35 \mathrm{~d}$ for Ross 308 and Cobb 500 males maintained on 8- or 16-h photoperiods, or transferred from 8- to 16- $\mathrm{h}$ photoperiods at 10 (INC10), 15 (INC15) or $20 \mathrm{~d}(\mathrm{INC} 20)$

\begin{tabular}{|c|c|c|c|c|c|}
\hline Treatment & $\begin{array}{l}\text { Body weight } \\
\text { (g) }\end{array}$ & $\begin{array}{l}\text { Feed intake } \\
\text { (g/bird) }\end{array}$ & $\begin{array}{c}\text { FCE } \\
(\mathrm{g} / \mathrm{kg} \text { feed })^{1}\end{array}$ & $\begin{array}{l}\text { Total mortality } \\
(\%)^{2}\end{array}$ & $\begin{array}{c}\text { Sudden Death } \\
\text { Syndrome }(\%)^{2}\end{array}$ \\
\hline & $21 \mathrm{~d}$ & \multicolumn{4}{|c|}{0 to $21 \mathrm{~d}$} \\
\hline constant $8 \mathrm{~h}$ & 838 & 1069 & 743 & $3.2(0.17)$ & $0.3(0.03)$ \\
\hline constant $16 \mathrm{~h}$ & 830 & 1109 & 710 & $3.8(0.19)$ & $0.1(0.02)$ \\
\hline INC10 & 822 & 1090 & 714 & $2.9(0.16)$ & $0.1(0.02)$ \\
\hline INC15 & 816 & 1070 & 721 & $4.3(0.20)$ & $0.4(0.03)$ \\
\hline INC20 & 815 & 1063 & 726 & $3.1(0.17)$ & $0.5(0.06)$ \\
\hline Cobb & $841^{\mathrm{a}}$ & 1088 & 734 & $3.8(0.19)$ & $0.1(0.01)$ \\
\hline Ross & $807^{b}$ & 1072 & 711 & $3.1(0.17)$ & $0.5(0.05)$ \\
\hline $\begin{array}{l}\text { Pooled s.e.d. } \\
\text { Lighting } \\
\text { Genotype }\end{array}$ & $\begin{array}{r}25.7 \\
8.5 \\
\end{array}$ & $\begin{array}{r}19.3 \\
9.1 \\
\end{array}$ & $\begin{array}{r}19.5 \\
9.1 \\
\end{array}$ & $\begin{array}{l}(0.044) \\
(0.023) \\
\end{array}$ & $\begin{array}{l}(0.036) \\
(0.019) \\
\end{array}$ \\
\hline Genotype & 22 to $35 \mathrm{~d}$ & \multicolumn{4}{|c|}{22 to $35 \mathrm{~d}$} \\
\hline $\begin{array}{l}\text { constant } 8 \mathrm{~h} \\
\text { constant } 16 \mathrm{~h} \\
\text { INC10 } \\
\text { INC15 } \\
\text { INC20 }\end{array}$ & $\begin{array}{l}1430 \\
1356 \\
1407 \\
1419 \\
1424\end{array}$ & $\begin{array}{l}2673 \\
2645 \\
2564 \\
2700 \\
2643\end{array}$ & $\begin{array}{l}535 \\
513 \\
549 \\
526 \\
539\end{array}$ & $\begin{array}{l}2.0(0.12)^{\mathrm{a}} \\
0.6(0.05)^{\mathrm{b}} \\
1.9(0.12)^{\mathrm{ab}} \\
0.9(0.09)^{\mathrm{ab}} \\
1.1(0.10)^{\mathrm{ab}}\end{array}$ & $\begin{array}{l}1.0(0.09)^{\mathrm{a}} \\
0.3(0.03)^{\mathrm{ab}} \\
0.8(0.06)^{\mathrm{ab}} \\
0.1(0.02)^{\mathrm{b}} \\
0.5(0.07)^{\mathrm{ab}}\end{array}$ \\
\hline $\begin{array}{l}\text { Cobb } \\
\text { Ross }\end{array}$ & $\begin{array}{l}1411 \\
1403\end{array}$ & $\begin{array}{l}2641 \\
2649\end{array}$ & $\begin{array}{l}534 \\
530\end{array}$ & $\begin{array}{l}1.8(0.12) \\
0.8(0.07)\end{array}$ & $\begin{array}{l}0.9(0.08)^{\mathrm{a}} \\
0.2(0.02)^{\mathrm{b}}\end{array}$ \\
\hline $\begin{array}{l}\text { Pooled s.e.d. } \\
\text { Lighting } \\
\text { Genotype }\end{array}$ & $\begin{array}{l}31.3 \\
12.7 \\
\end{array}$ & $\begin{array}{l}58.8 \\
24.1 \\
\end{array}$ & $\begin{array}{c}16.4 \\
8.3 \\
\end{array}$ & $\begin{array}{l}(0.024) \\
(0.030) \\
\end{array}$ & $\begin{array}{l}(0.022) \\
(0.019) \\
\end{array}$ \\
\hline Genotype & $35 \mathrm{~d}$ & \multicolumn{4}{|c|}{0 to $35 \mathrm{~d}$} \\
\hline $\begin{array}{l}\text { constant } 8 \mathrm{~h} \\
\text { constant } 16 \mathrm{~h} \\
\text { INC10 } \\
\text { INC15 } \\
\text { INC20 }\end{array}$ & $\begin{array}{l}2267 \\
2186 \\
2229 \\
2234 \\
2239\end{array}$ & $\begin{array}{l}3743 \\
3754 \\
3654 \\
3769 \\
3705\end{array}$ & $\begin{array}{l}594 \\
571 \\
598 \\
581 \\
593\end{array}$ & $\begin{array}{l}5.3(0.22) \\
4.4(0.20) \\
4.7(0.21) \\
5.1(0.23) \\
4.3(0.21)\end{array}$ & $\begin{array}{l}1.3(0.11) \\
0.4(0.04) \\
0.9(0.08) \\
0.5(0.05) \\
1.0(0.10)\end{array}$ \\
\hline $\begin{array}{l}\text { Cobb } \\
\text { Ross } \\
\text { Pooled s.e.d. }\end{array}$ & $\begin{array}{l}2252 \\
2210\end{array}$ & $\begin{array}{l}3729 \\
3721\end{array}$ & $\begin{array}{l}593 \\
582\end{array}$ & $\begin{array}{l}5.6(0.24) \\
3.6(0.19)\end{array}$ & $\begin{array}{l}0.9(0.08) \\
0.7(0.07)\end{array}$ \\
\hline $\begin{array}{l}\text { Lighting } \\
\text { Genotype }\end{array}$ & $\begin{array}{l}34.2 \\
19.5\end{array}$ & $\begin{array}{l}63.5 \\
26.3\end{array}$ & $\begin{array}{r}10.0 \\
8.1\end{array}$ & $\begin{array}{l}(0.044) \\
(0.025)\end{array}$ & $\begin{array}{l}(0.036) \\
(0.021)\end{array}$ \\
\hline
\end{tabular}


Table 2 Mean body weight, feed intake, feed conversion ratio, and total mortality at $21 \mathrm{~d}$, from 22 to 35 or $42 \mathrm{~d}$, and at 35 or $42 \mathrm{~d}$ for Ross 308 and Cobb 500 males (current study) and females (Lewis \& Gous, 2007) maintained on 8- or 16-h photoperiods, or transferred from 8- to 16- h photoperiods at 20 or $21 \mathrm{~d}$

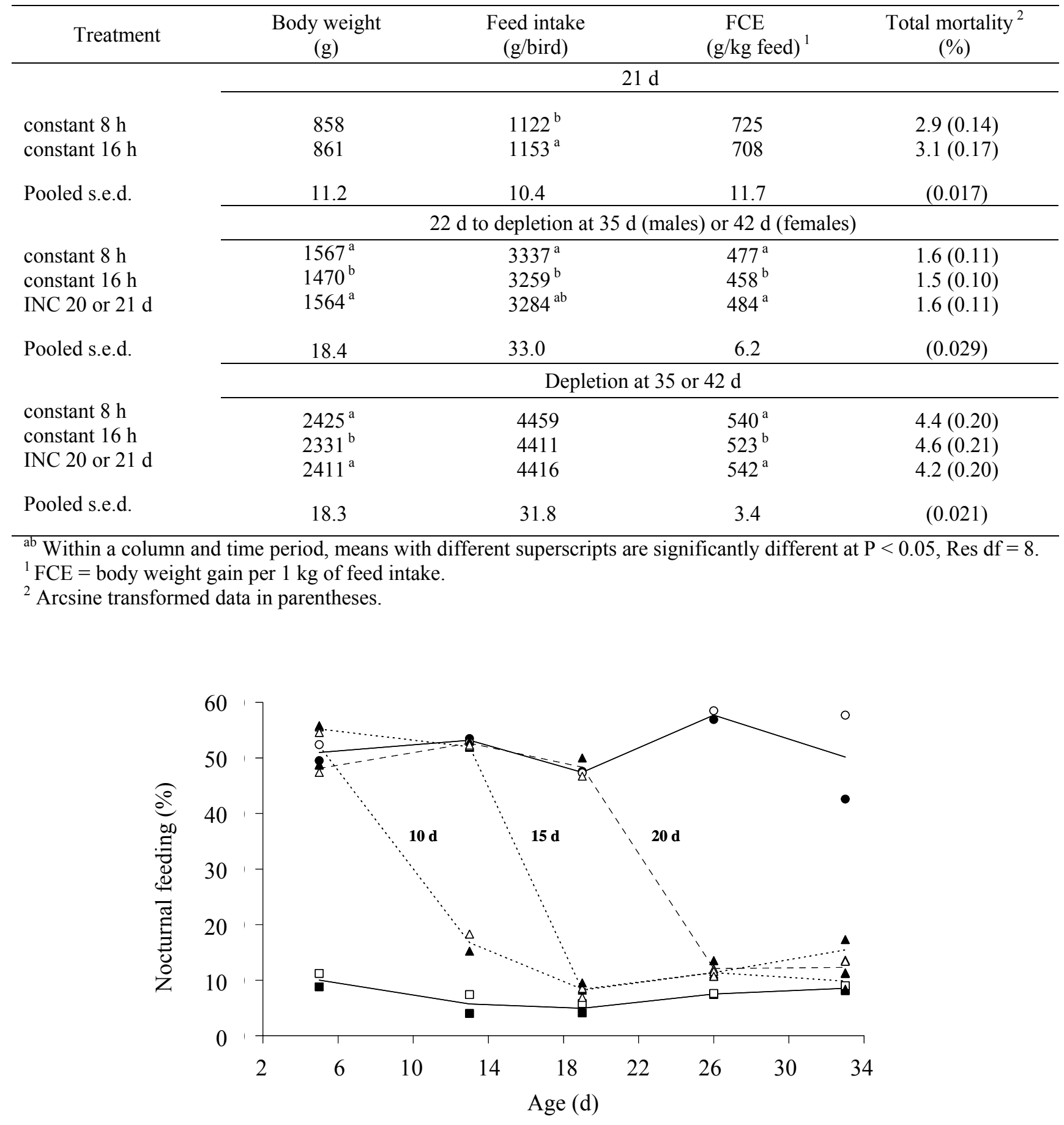

Figure 1 Percentage of daily feed intake consumed during the dark period by Cobb (open symbols) and Ross (solid symbols) male broilers maintained on $8-(\circ, \bullet)$ or 16 -h photoperiods $(\square, \boldsymbol{\square})$, or transferred from 8- to 16 -h photoperiods at 10,15 , or $20 \mathrm{~d}$ of age $(\Delta, \boldsymbol{\Delta})$. Solid lines represent the mean of the two genotypes for birds maintained on 8-h (upper) or 16-h (lower) photoperiods and broken lines represent the means for birds transferred from 8 to $16 \mathrm{~h}$. 
weight gains and better feed conversion efficiencies than, but similar feed intakes to, constant 16-h birds. None of the INC performance traits was significantly different from those of birds maintained on $8 \mathrm{~h}$. Total mortality was consistently similar for all groups.

\section{Discussion}

The responses of both genotypes in this study (males) to constant 8-h, 16-h or increasing lighting regimens were similar to those for female birds of the same two genotypes reported by Lewis \& Gous (2007). However, the similar body weights at $21 \mathrm{~d}$ for all lighting regimens but larger terminal body weights for constant 8-h and increased-lighting groups (Table 2) contrast with findings from the original increasing lighting trials (e.g., Classen \& Riddell, 1989; Classen et al., 1991). In those studies, birds that had been initially exposed to 6-h photoperiods had lower body weights at $21 \mathrm{~d}$, but similar body weights at depletion to constant 23-h controls after their photoperiod had been increased to $23 \mathrm{~h}$. It is possible that the constant 8-h and increasing lighting groups in the current and Lewis \& Gous (2007) studies may have had superior body weights at, and better feed conversion efficiency to, depletion to 16-h birds (Table 2) because they performed markedly more nocturnal feeding (Figure 1). Whereas in the original increasing-light studies, increasing-light and 23-h birds had similar body weights, a recent study showed that increasing-light birds consumed more feed and had larger body weights than either constant 14 or 23-h groups (Schwean-Lardner et al., 2006), and this offers support for the nocturnal feeding hypothesis. Unfortunately, none of these early trials included a constant short-day control with which to compare the performance of the constant 8-h birds in these recent studies. However, the superior performance but similar liveability of birds maintained on 8-h photoperiods in this study and in the earlier investigation with females (Lewis \& Gous, 2007) do not support the conclusions of Lewis \& Morris (2006) that broilers held on $8 \mathrm{~h}$ have a lower feed intake, smaller body weight, similar feed conversion efficiency, but improved liveability to $16-\mathrm{h}$ birds. The data reviewed by Lewis \& Morris (2006) were from trials conducted more than 15 years ago, since which time, mean daily body weight gain and feed intake has increased markedly (Laughlin, 2007), so it is likely that the broiler's response to photoperiodic influences has changed.

Classen (1992) stated that the hypothesis for the investigation of increasing lighting regimens was that the use of short photoperiods early in life might reduce initial feed intake and growth and, by so doing, reduce overall mortality through a reduction in the incidences of conditions associated with rapid initial growth (e.g., various leg disorders and SDS). Indeed, the increasing regimens in most of the early studies consistently resulted in fewer leg disorders and lower incidences of SDS, thus improving overall liveability (Lewis \& Morris, 2006). The most likely reason for the lack of such improvements in liveability in the current studies was that growth to $21 \mathrm{~d}$, unlike in the early studies, had not been depressed by rearing on short days (Table 2). Additionally, reductions in the incidence of leg disorders have been achieved through genetic selection and advances in nutrition (Laughlin, 2007).

The faster body weight gains observed in the early trials after the birds had been transferred from 6 to $23 \mathrm{~h}$ was considered to be a consequence of compensatory growth (e.g., Classen, 1992). However, both the constant short-day and the groups transferred from 8 to $16 \mathrm{~h}$ in the recent studies had similar body weights to constant 16-h birds at $21 \mathrm{~d}$, and therefore had no catching up to do, yet all still had superior growth after $21 \mathrm{~d}$ to long-day controls; this suggests that compensatory growth was likely to have been only one of the factors in the original increasing-light studies. Indeed, Classen (1992) also suggested that the increase from 6 to $23 \mathrm{~h}$ may have triggered an increase in the release of testosterone to stimulate faster growth in the period after $21 \mathrm{~d}$. However, the current findings question the involvement of photoinduced anabolic steroid release, because the groups transferred from 8 to $16 \mathrm{~h}$ had similar body weight gains between $22 \mathrm{~d}$ and depletion to the birds maintained on short days (and therefore not photostimulated). The hypothalamo-pituitary axis of a broiler is functional by three weeks of age (Dunn et al., 1990) and the model of Lewis \& Morris (2004) predicts that an increase from 8 to $16 \mathrm{~h}$ would elicit a photosexual response more than double that of a transfer from 6 to $23 \mathrm{~h}$, and so, if the superior growth and feed conversion after $21 \mathrm{~d}$ in the original studies were the result of a photoinduced increase in testosterone release, the weight gain between $22 \mathrm{~d}$ and depletion in the birds transferred from 8 to $16 \mathrm{~h}$ in the current studies should have been larger than that of the constant short-day controls; it was not. One possible reason for the larger weight gain by the short-day birds after $22 \mathrm{~d}$, relative to constant long-day birds, is the lower anticipated energy expenditure during darkness compared with light. MacLeod et al. (1988) concluded that fowl expend about 1\% per hour less energy in 
darkness than in light, and so birds exposed to $8 \mathrm{~h}$ would expend about $8 \%$ less energy than birds given $16 \mathrm{~h}$. The pooled data in Table 2 show that birds maintained on $8 \mathrm{~h}$ had heavier body weights at depletion than birds maintained on $16 \mathrm{~h}$, despite a similar feed intake, and so, with approximately $1.9 \mathrm{~g}$ of feed required to produce $1 \mathrm{~g}$ of body weight, the $4 \%$ superior growth of the short-day birds can be satisfactorily explained by the anticipated 8\% reduction in energy expenditure. Notwithstanding that this could explain the superior growth and feed conversion (post $21 \mathrm{~d}$ ) for 8-h compared to 16-h birds, it does not explain why the birds transferred from 8 to $16 \mathrm{~h}$ also had superior performance to the constant $16-\mathrm{h}$ birds in the period after the change to long days, because at that time they received the same amount of illumination. One hypothesis is that feed consumed during darkness is converted more efficiently than that consumed during light, and so the birds transferred from 8 to $16 \mathrm{~h}$, despite having a similar feed intake to constant 16-h birds, had a larger weight gain and more efficient feed conversion after $21 \mathrm{~d}$ because, though to a lesser extent than before, they continued to eat more feed in the dark period than the constant 16-h birds. In contradiction of this theory, Cherry \& Barwick (1962) reported that broilers maintained in complete darkness from $7 \mathrm{~d}$ had similar body weights and feed conversion efficiencies to 10 weeks of age to continuously illuminated birds. However, the growth potential and appetite of modern broilers are much greater than that of the genotypes used by Cherry \& Barwick ( 725 vs. $2100 \mathrm{~g}$ body weight; 1.3 vs. $3.6 \mathrm{~kg}$ feed intake at $35 \mathrm{~d}$ ) so their response to nocturnal feeding may also be different. Weaver \& Siegel (1968) observed minimal nocturnal feeding throughout a 56$\mathrm{d}$ experiment by broilers exposed to 8-h photoperiods, which contrasts with the broilers in the current study having learnt to eat half their daily feed intake in the dark period within $4 \mathrm{~d}$ of the abrupt transfer from continuous to $8 \mathrm{~h}$ illumination on day 2 . This shows the importance of continuously providing feed when short daylengths are used in commercial practice.

The data in Table 1 suggest that transferring birds from 8 to $16 \mathrm{~h}$ at $10 \mathrm{~d}$ and an estimated body weight of $275 \mathrm{~g}$ suppresses feed intake in the period after $21 \mathrm{~d}$, but with minimal reduction in growth, compared with transfers at $15 \mathrm{~d}$ and $510 \mathrm{~g}$ or $20 \mathrm{~d}$ and $780 \mathrm{~g}$ body weight. However, there is no obvious explanation for this anomalous response, especially when much of the difference in feed intake occurred in the final $7 \mathrm{~d}$ of the trial, there were no significant differences in overall body weight or feed conversion efficiency to $35 \mathrm{~d}$, and nocturnal feeding behaviours were similar for all step-up groups at $33 \mathrm{~d}$. Support for this being an incongruent finding are the non-significant differences in feed intake, body weight and feed conversion at both five and six weeks of age in a trial in which natural light (latitude $30^{\circ} \mathrm{N}$ ) was artificially supplemented to provide continuous illumination from various starting ages between one and five weeks (Stanley et al., 1997). It should be concluded that age at transfer from short to long days, at least when made between 10 and $20 \mathrm{~d}$, has little effect on performance, because the feed intake and body weight gain of birds given an increase in daylength and constant short-day controls were similar at all stages of growth.

\section{Acknowledgement}

The authors acknowledge the financial contribution of the Protein Research Foundation to this study.

\section{References}

Analytical Software, 2003. Statistix Version 8, Tallahassee, FL 32317, USA.

Cherry, P. \& Barwick, M.W., 1962. The effect of light on broiler growth. II. Light patterns. Br. Poult. Sci. 3 , 41-50.

Classen, H.L., 1992. Management of leg disorders. In: Bone Biology and Skeletal Disorders in Poultry. Ed. Whitehead, C.C., Carfax Publishing Company, Abingdon. pp. 195-211.

Classen, H.L. \& Riddell, C., 1989. Photoperiodic effects on performance and leg abnormalities in broiler chickens. Poult. Sci. 68, 873-879.

Classen, H.L., Riddell, C. \& Robinson, F.E., 1991. Effects of increasing photoperiod length on performance and health of broiler chickens. Br. Poult. Sci. 32, 21-29.

Dunn, I.C., Sharp, P.J. \& Hocking, P.M., 1990. Effects of interactions between photostimulation, dietary restriction and dietary maize oil dilution on plasma LH and ovarian and oviduct weights in broiler breeder females during rearing. Br. Poult. Sci. 31, 415-427.

Laughlin, K., 2007. The UK industry. In: The Evolution of Genetics, Breeding and Production - Temperton Fellowship Report 15. Harper Adams University College, Newport. pp. 39-48. 
Lewis, P.D. \& Gous, R.M., 2007. Broilers perform better on short or step-up photoperiods. S. Afr. J. Anim. Sci. 37, 90-96.

Lewis, P.D. \& Morris, T.R., 2004. Research note: amendments to the model for predicting age at sexual maturity for growing pullets of layer strains following changes in photoperiod. J. Agric. Sci. 142, 613-614.

Lewis, P.D. \& Morris, T.R., 2006. Photoperiod: conventional programmes. In: Poultry Lighting the Theory and Practice. Northcot, Andover. pp. 23-55.

MacLeod, M.G., Jewitt, T.R. \& Anderson, J.E.M., 1988. Energy expenditure and physical activity in domestic fowl kept on standard and interrupted lighting patterns. Br. Poult. Sci. 29, 231-244.

Schwean-Lardner, K., Classen, H.L. \& Fancher, B.I., 2006. Increasing lighting program effects on production characteristics of modern broilers. Poult. Sci. 86, Suppl. 1, 165.

Stanley, V.G., Gutierrez, J., Parks, A.L., Rhoden, S.A., Chukwu, H., Gray, C. \& Krueger, W.F., 1997. Relationship between age of commercial broiler chickens and response to photostimulation. Poult. Sci. 76, 306-310.

Weaver Jnr., W.D. \& Siegel, P.B., 1968. Photoperiodism as a factor in feeding rhythms of broiler chickens. Poult. Sci. 47, 1148-1154. 